\title{
Margaret McCartney: We lack the tools to help patients decide about statins
}

\author{
Margaret McCartney general practitioner, Glasgow
}

The National Institute for Health and Care Excellence (NICE) recently approved atorvastatin for people in England and Wales who have a $10 \%$ risk of a cardiovascular event within 10 years; it had previously been a $20 \%$ risk. ${ }^{1}$ GPs are advised to treat such people - which includes everyone older than 85-and to continually review everyone else in case they pass the $10 \%$ threshold.

This decision on funding statins is based primarily on cost effectiveness to the NHS. ${ }^{2}$ The press release from NICE mentioned the potential benefit to the population (namely, it "could help prevent up to 28000 heart attacks and 16000 strokes each year" ${ }^{\prime 3}$ ) but not the absolute benefit to the individual. But life is more complicated than that: people make choices for multiple reasons. Many patients stop taking statins after starting them ${ }^{4}$; others, faced with the choice of taking a drug with a small chance of benefit, would rather not do so; and some people will want to take them no matter how low their risk may already be.

We lack the tools to accurately predict individual risk at such low thresholds-leading to overtreatment and, to a lesser extent, non-identification of risk. ${ }^{5}$ The general practice cake is finite; cutting a bigger slice for healthy people at lower risk means a smaller slice for people who have symptoms and are unwell. The chance of a longer life is offered to people who are willing to take tablets consistently, but we know that these compliant patients are already more likely to live longer, even when taking a placebo. ${ }^{67}$ This policy, which benefits people who are already the healthiest, has the potential to widen health inequalities.

Who is keeping an overview of where NICE is taking us? The conflicts of interest among the members on its drafting panels are buried in minutes rather than in the guidance itself, and we still lack public access to most of the trial data that NICE uses. ${ }^{8}$ But we are told to press ahead regardless when, most bewildering of all, we don't have a decent shared decision aid-designed and tested for the five million more people advised to take statins - about the benefits and harms of statinisation and the management of cardiovascular risk.

"Should I take statins?" is a question asked of GPs every day. We urgently need better tools to allow guidance to guide, rather than dictate new targets. Our lack of resources to deal with such a common question simply isn't acceptable.

Competing interests: I have read and understood the BMJ policy on declaration of interests and declare the following interests: I'm an NHS GP partner, with income partly dependent on Quality and Outcomes Framework (QOF) points. I'm a part time undergraduate tutor at the University of Glasgow. I've written a book and earned from broadcast and written freelance journalism. I'm an unpaid patron of Healthwatch. I make a monthly donation to Keep Our NHS Public. I'm a member of Medact. I'm occasionally paid for time, travel, and accommodation to give talks or have locum fees paid to allow me to give talks but never for any drug or public relations company. I was elected to the national council of the Royal College of General Practitioners in 2013.

Provenance and peer review: Commissioned; not externally peer reviewed.

Follow Margaret McCartney on Twitter, @mgtmccartney

NHS England. The National Institute for Health and Care Excellence (Constitution and Functions) and the Health and Social Care Information Centre (Functions) Regulations 2013. 1 April 2013. www.legislation.gov.uk/uksi/2013/259/contents/made.

2 National Institute for Health and Care Excellence. Lipid modification: cardiovascular risk assessment and the modification of blood lipids for the primary and secondary prevention of cardiovascular disease. July 2014. www.nice.org.uk/guidance/CG181/chapter/1Recommendations.

3 National Institute for Health and Care Excellence. Press release: Wider use of statins could cut deaths from heart disease. 18 July 2014 www.nice.org.uk/News/Article/wideruse-of-statins-could-cut-deaths-from-heart-disease.

4 Hinchliffe A, Public Health Wales. Patient adherence to treatment with statins for the prevention of cardiovascular disease: rapid review of the evidence. 24 March 2011. www. wales.nhs.uk/sitesplus/documents/986/Adherence\%20with\%20statins\%20to\%20prevent\% 20CVD-\%20literature\%20review\%202011\%20v1\%200.pdf.

5 Collins G, Altman DG. An independent and external validation of QRISK2 cardiovascular disease risk score: a prospective open cohort study. BMJ 2010;340:c2442.

6 Curtis JR, Larson JC, Delzell E, Brookhart MA, Cadarette SM, Chlebowski R, et al. Placebo adherence, clinical outcomes, and mortality in the women's health initiative randomized hormone therapy trials. Med Care 2011:49:427-35.

7 Coronary Drug Project Research Group. Influence of adherence to treatment and response of cholesterol on mortality in the coronary drug project. N Engl J Med 1980;303:1038-41.

8 McPherson K. Letter: Concerns about the latest NICE draft guidance on statins. BMJ 2014;349:g4130.

Cite this as: BMJ 2014;349:95688

(๑) BMJ Publishing Group Ltd 2014 